\title{
PROFITABILITY MEASUREMENT AND ANALYSIS IN ESTONIAN BUSINESS PRACTICE
}

\author{
Maret Branten \\ EuroAcademy, Tallinn, Estonia \\ Jaan Alver \\ Tallinn University of Technology
}

\begin{abstract}
The paper considers whether and how Estonian companies use and analyze the profitability measures. On the one hand, profitability measures should be a central component of the management control systems, but on the other hand, they should be linked to the wealth measurement objective. In this context, the importance of a quality analysis in companies cannot be overestimated. The activities of Estonian companies and their attitudes to profitability analysis have been considered by using the results of a survey carried out in companies. The survey aims to draw attention to areas, which need improvement. It has been shown how the companies make use of the traditional income statement in the analysis process and whether any adjustment is needed; whether profits as a manifestation of the value of a company merit attention; whether attention is accorded to the capital maintenance problem and the price of capital - hence the real growth of the wealth; whether the cash-based profit or contribution margin, for example, are analyzed. An accountant's role in the analysis process is also under consideration.
\end{abstract}

Keywords: Estonia, income statement, profitability analysis, profitability measures

JEL code: M21, M41

\section{Introduction}

Profit is one of the key elements of information upon which the functioning of a private, free enterprise economy depends (Bray, 1949). Profitability measures are important, essential components of the management control systems of businesses. They motivate managers and employees at all levels of an organization to achieve the organization's goals. Performance evaluation and rewards are key elements for motivating individuals in an organization. Profit measures should also be linked to the objectives of wealth measurement.

The objective of this research is to elucidate the overall attitude of Estonian companies toward interpreting the profit indicators, i.e. which profit and profitability indicators are used by companies when analyzing their activities and when passing investment decisions; and to determine the extent to which the profit indicators are available in regular report forms; and whether or not they pay attention to capital maintenance and value added.

The research considers internal and external financial measures based on accounting figures, which are routinely reported by legal business entities and also considers how familiar respondents are with different profit indicators.

A questionnaire survey, created by the authors, was conducted among the companies with the purpose of finding out: which figures are needed from the regular income statement and whether some indicators of income statement and balance sheet are adjusted in order to obtain necessary information for analysis. The survey seeks to determine the capital maintenance issue taken into regard; whether profit as an indicator of change in company value is valuated; whether the profit and the investments are compared in order to find out the actual growth in wealth; and if the cash-based profit is analyzed. 
The survey is of special interest, because we are dealing with companies in a state with a brief history of a market economy, with its models of analysis and management information still in the early stage of formation.

\section{Theoretical background}

Profit as an important business indicator and as one possible paradigm of financial accounting theory - the ideal-profit paradigm, which specifies the measurement of performance as the domain of accounting (Riahi-Belkaoui, 2004) - has long been the subject of academic discussion and has been used in financial accounting practice in various ways. In this paradigm, one must ask: what is the nature of profit and when should profit be reported? Unlike the idea of profit in economic theory, net profit does not exist as a well-defined economic construct under the real-world conditions in which accounting operates.

Given that there is no consensus on a well-defined concept of net profit, the fundamental problem of financial accounting theory is how to design and implement concepts and standards that best trade off the investor-informing and the manager performance-evaluating roles of accounting information (Scott 2009). This poses a problem, because the lack of a well-defined concept of net profit means that much judgment must be exercised in the process of asset valuation and profit measurement (ibid.). Over the past decades, various schools have presented different options in addressing this issue. Classic normative theories of business profit, realizable profit and realized profit (Edwards and Bell, 1961; Chambers, 1966; Sterling, 1970) have been proposed by empirical studies to describe the relationship of accounting information to the value of an enterprise (Schroeder et al. 2012). This work includes well-known studies by Ohlson, Feltham and others (Ohlson, 1989; Ohlson, 1990; Ohlson, 1991; Ohlson, 1995; Feltham and Ohlson, 1995).

Some authors, e.g. Christensen and Demski (2003), consider the accounting theory from an information content perspective that identifies the substance of the accounting report with the information it conveys. They distinguish between valuation and information contents - the valuation school, for example, emphasizes stocks and flows of values, but in practice it steps away from problematic valuations. Neither is the current IASB treatment for determining profit free of problems. Barker (Barker, 2010) and Nobes (Nobes, 2012) have highlighted the inconsistencies in definitions and various contentious issues that focus on the concept of profit and how to determine it.

In this fluid situation, the several theoretical schools put emphasis on different aspects of informational values of profit; these different frameworks of financial accounting offer a variety of approaches for the measurement of profit and for reporting and interpreting it. This work considers an enterprise-oriented view of profit and the analysis of profitability in Estonia.

The Estonian guidelines, in effect, are a simplified subset of the IFRS for SME.

The IFRS for SME do not specify fixed income statement formats. The Estonian Accounting Act prescribes a format: there is an option to elect one among two income statement schemes. Underlying the difference between the two layouts is the classification of expenses: in Format 1, the expenses are classified by nature, in Format 2 by function.

In Estonia, since 2009 it has been obligatory to present the comprehensive income statement. This study intends to analyze the use of profit and profitability indicators in Estonian business practices, with recourse to a survey of the respective topic, carried out at companies, with the goal of discovering, which preference is given by the Estonian companies when the efficiency of business activities is analyzed and for the purpose of 
measurement. Similar surveys have been performed in other countries with a brief history of a market economy. For instance, in Latvia a survey has been conducted for improving the model of analysis of financial reports, consisting of the estimates of companies on the importance of various financial indicators (Kasalis 2005) and the research on the relationship of cash flow with other indicators (Subatnieks 2007). In Slovenia, studies have been done to determine the conceptions used by companies as they consider which indicators are important for performance measurement (Marc et al. 2010). The latter study contains interesting material for comparison with the present study: it used as a polling method, the 5-grade Likert-type scale questionnaire, the same scale used in our questionnaire. These research studies handle a broader range of indicators when compared with the present research, focusing on finding out the attitudes of companies with regard to the analysis of profit.

\section{Empirical study}

\subsection{Methodology}

The questionnaire survey method was applied for data collection with the survey subjects in Estonian companies. The survey questionnaire was distributed to accountants or finance managers, depending on who is responsible for the analysis in the company.

The questionnaire has been composed as follows. Six blocks of questions, 17 statements in total, were constructed with Likert-type scale answers. For every statement, there were five reply options. Depending on a question, the options were: 'always, frequently, sometimes, very rarely, never at all' or 'agree, rather agree, neither agree nor disagree, rather disagree, disagree'. In other words, a 5-grade scale was used, where full consent with the statement was rated as ' 5 ' and full non-consent was rated as ' 1 '. In addition, the questionnaire contained six questions with selected responses, mainly to classify the companies and respondents. The types of questions were as follows: two first groups included in addition to closed-ended questions an open-ended question; the remaining were closed-ended questions.

The principles of the formation of the sample are as follows. When considering the problem, it is essential to note the nature and the sizes of the companies that were analyzed, especially the larger enterprises. The companies studied have $\geq 50$ workers and belong to the activity areas of industry and energy, building and real estate development, trade, service. The whole population included 535 companies. Included in the sample were 100\% out of the aforementioned companies. The questionnaires were self-completion questionnaires, distributed to respondents of this group by e-mail, and the responses were received by e-mail. We got answers from 117 businesses; the response rate was 22\%. The distribution of the sample according to the number of employees in the company was as follows: 250 and more employees - 41 companies; 50-249 employees - 76 companies. The company breakdown according to areas of activity was as follows: industry and energy - 56 companies; building and real estate development - 17 companies; trade - 35 companies; service - 13 companies. Four companies have two areas of activity. The sample in terms of the office held by respondents was as follows: finance manager (finance analyst) - 64 people; (chief) accountant -53 people.

The analysis was carried out in different groups: with regard to the whole sample; grouped according to the size of the company - large and medium entities; grouped by the position of the respondent - finance managers (financial analysts) and accountants; grouped by the activity areas of the company; grouped by users of income statement Format 1 or Format 2.

Subjected to analysis have been arithmetic means, modes and medians. To elucidate the statistical importance of differences in assessments of the mentioned groups, z-tests have been carried out. To determine the links of interest, a correlation analysis has been used. 


\subsection{Analysis of Results}

The first group of questions included in the survey determined whether and how the companies use the regular income statement in their financial analysis. The statements in the questionnaire were as follows:

I use the income statement when analyzing the performance of the company as follows: a) I calculate profitability indicators; b) for comparison with competitors; c) for other purposes (please specify).

Table 1 presents the mean scores, modes and medians.

Table 1. Usage of income statement when analyzing the company performance (5 - always; 4 - frequently; 3 - sometimes; 2 - very rarely; 1 - never at all)

\begin{tabular}{|l|c|c|c|}
\hline Manner of use of the Income statement & Arithmetic mean & Mode & Median \\
\hline Calculation of profitability indicators & 4.06 & 5 & 4 \\
\hline Comparison with competitors & 3.08 & 3 & 3 \\
\hline For other purposes & 2.51 & 1 & 2 \\
\hline
\end{tabular}

a) Calculation of profitability indicators.

The average estimate is 4.06 , i.e. the closest to the estimate label 'frequently'. The responses distribute as follows: always $45 \%$; frequently $29 \%$; sometimes $17 \%$; very rarely $7 \%$, never at all $2 \%$. Thus, calculation of profitability indicators takes place in the majority of companies, whereas $45 \%$ of respondents calculate profitability indicators always and $29 \%$ frequently. Only $2 \%$ of the respondent companies do not calculate.

b) Comparison with profits of competitors.

The average estimate is 3.08 , i.e. close to the estimate label 'sometimes'. The distribution of estimates is as follows: sometimes $31 \%$; very rarely $23 \%$; frequently $21 \%$; always $15 \%$; never at all $10 \%$. Comparison with the data of competitors takes place always in $15 \%$ of respondent companies and frequently in $21 \%$ companies. In $10 \%$ of the companies it never takes place.

c) Open-ended question: For other purposes (please specify).

The average estimate is 2.51 ; hence 'very rarely'.

Respondents more often specified performance of analysis of subunits and comparison with budget and plan indicators.

The second group of questions surveys preferences of the companies when using various profit figures in business analysis.

The question was posed to 8 profit figures: a) Operating profit; b) Gross profit; c) Earnings before taxes (EBT); d) Net profit; e) EBITDA; f) Contribution margin; g) Cash based profit; h) Other (please specify). 
Table 2 presents the means, modes and medians of the responses.

Table 2. Use of various profit numbers in the analysis

(5 - always; 4 - frequently; 3 - sometimes; 2 - very rarely; 1 - never at all)

\begin{tabular}{|l|c|c|c|}
\hline Profit indicator & Arithmetic mean & Mode & Median \\
\hline Operating profit & 4.22 & 5 & 5 \\
\hline Net profit & 4.14 & 5 & 4 \\
\hline Gross profit & 4.01 & 5 & 4 \\
\hline EBITDA & 3.67 & 5 & 4 \\
\hline Earnings before taxes & 3.43 & 5 & 2 \\
\hline Contribution margin & 2.63 & 1 & 1 \\
\hline Cash based profit & 1.94 & 1 & 1 \\
\hline Other & 1.64 & 1 & \\
\hline
\end{tabular}

As revealed from Table 2, the most popular indicator is the operating profit (average 4.22; mode 5; median 5). $52 \%$ of the respondents use operating profit always and $29 \%$ frequently.

Net profit has a slightly lower average (average 4.14; mode 5; median 4) and gross profit (average 4.01; mode 5; median 4). Net profit is used always by $50 \%$ of the respondent companies and frequently by $27 \%$. Gross profit is used always by $46 \%$ of companies and frequently by $26 \%$.

The three profit indicators mentioned above are probably preferred because of their simplicity and familiarity and also because of the fact that several well-known profitability ratios are based on those profit indicators.

The analysis of the cash-based profit is not so popular (mean score 1.94, falling in between estimates 'very rarely' and 'never at all; mode 1; median 1). 53\% of respondents never use the cash-based profit, 24\% use it very rarely, and 9\% use it always. Dismissing the cash-based profit, i.e. the quality of profit ratio, is a significant shortcoming in estimating the company's business activities. Companies' managers frequently are not able to distinguish accrual-based profit and cash (cash-based profit), failing to study the actual receipt of cash. This may result in insolvency. In general, an opinion has been expressed that the use of cash-based profit rather than accrual-based profit would provide a more accurate picture of a company.

The contribution margin as indicator is hardly ever used (average 2.63; mode 1; median 2). Contribution margin has never been used by $28 \%$ of respondents, $28 \%$ use it very rarely. It would pay off to give more attention to contribution margin, because, for example, when drawing the budget estimate, the income statement in the contribution margin format is very useful. Contribution margin also has a significant role in the issue of how the cost behavior impacts on profitability and adopting pricing decisions (Spaller, 2006).

EBITDA has been appreciated by the companies as middlemost (average 3.67; mode 5; median 4). Estimates distribute between possible variants: 'always' $36 \%$, 'frequently' $22 \%$, 'sometimes' $24 \%$, 'very rarely' $11 \%$ and 'never at all' $8 \%$. EBITDA merits more attention on the part of the Estonian companies. Under international estimates, analysts view EBITDA as the most informative profit indicator (Mosso, 2010). Hence, it would be worth considering establishing it as an interim outcome in income statements.

The open-ended question 'Other' was given as an answer in very few cases. There was one indicator that catches the eye: Gross profit - marketing expense as per production types. 


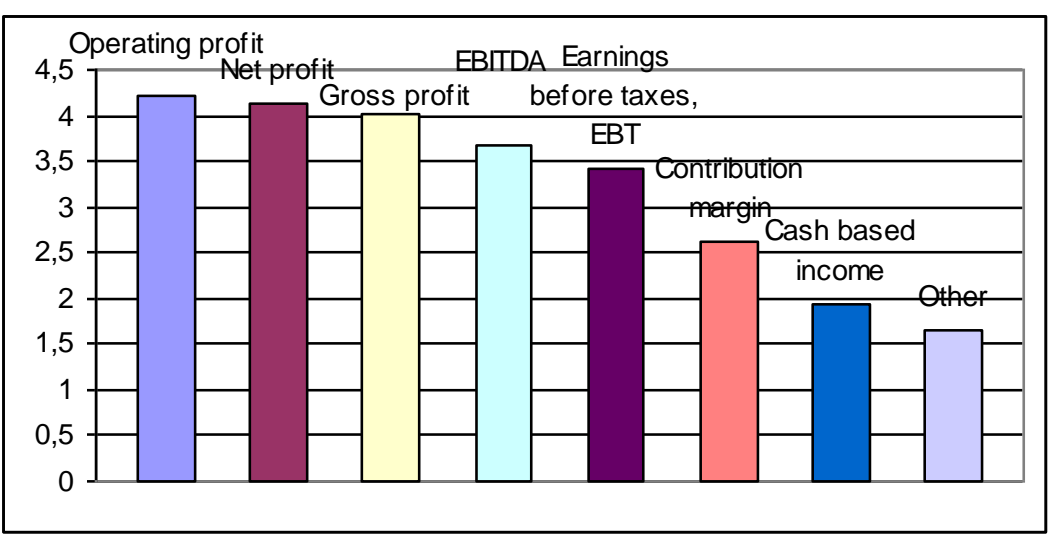

Figure 1. Average estimates of use of different profit figures ( 5 - always; 4 - frequently; 3 sometimes; 2 - very rarely; 1 - never at all)

The third question: For the analysis needed by the company, I adjust the regular income statement (and balance sheet).

The responses reveal that adjustment of reports occurs moderately (average 2.97; mode 3; median 3). Thus, the law-makers should consider the possibility of supplementing the reports, because the necessity in respect of grouping otherwise exists.

The fourth group of questions studies whether the companies calculate financial indicators and what indicators they use for reporting profit plus investments made therefore.

I calculate the following financial indicators:

a) RI (Residual Income),

b) EVA (Economic Value Added),

c) ROI (Return on Investment).

Table 3 characterizes the use of these indicators.

Table 3. Calculation of different indicators among the companies surveyed (5 - always; 4 frequently; 3 - sometimes; 2 - very rarely; 1 - never at all)

\begin{tabular}{|l|c|c|c|}
\hline \multicolumn{1}{|c|}{ Financial indicator } & Arithmetic mean & Mode & Median \\
\hline ROI $($ Return on investment $)$ & 3.12 & 4 & 3 \\
\hline EVA $($ Economic value added $)$ & 2.35 & 2 & 2 \\
\hline RI (Residual income $)$ & 2.11 & 1 & 2 \\
\hline
\end{tabular}

Table 3 reveals that with respect to indicators, most often used among the indicators studied is $R O I$ (average 3.12; mode 4; median 3). In case of EVA the average is 2.35; mode 2 and median 2 and in the case of $R I$ respectively $2.11 ; 1 ; 2$.

Probably $R O I$ is most popular because this ratio is well-known from literature and practice.

Low values of $E V A$ and $R I$ show that companies do not pay attention to actual growth of wealth. This is also corroborated by responses to the sixth question:

Differentiation between return on capital and return of capital will significantly improve the management decisions.

Response variants are: 5 - agree, 4 - rather agree, 3 -nor agree neither disagree, 2 - rather disagree, 1 - disagree.

This question has been dismissed by $9 \%$ of companies, testifying to the fact that the substance of the question has not been properly understood. Dominating among the respondents is the 
ranking of opinion between 'not agree neither disagree' and 'rather disagree' (average 2.43; mode 2; median 2).

Thus, it transpires that analysis of the value-based financial performance is weak in Estonian enterprises. This is most deplorable, because EVA could be put to a much wider use than just as a performance measure. At its best, EVA serves as the centerpiece of a completely integrated framework of financial management and incentive compensation (Stern et al. 1996).

By reference to estimates of the companies recovered in the survey, a correlation analysis was carried out in order to elucidate the strength of link between holding important the distinction of return on capital and return of capital and the use of RI, EVA and ROI. The link between holding important the distinction of return on capital and return of capital and the use of $R I$ may be estimated as being average: the value of correlation rate is 0.325 . In addition, the link between holding important the distinction of return on capital and return of capital and the use of $R O I$ may be estimated as average: the value of correlation rate is 0.324 . The link between holding important the distinction of return on capital and return of capital and the use of EVA, however, is very weak, as the correlation analysis indicates (the value of correlation rate is 0.200 ), a somewhat confounding outcome, because it is EVA that best expresses the value added. The complexity of the practical calculation of EVA may account for the fact - the regular income statement needs to be significantly revised. $R I$ can be viewed as a particular case of EVA, which is more easily implemented in practice. This explains the stronger correlation link with $R I$.

Companies' attitude to the importance of profit when making investment decisions has also been studied.

Statement: Profit indicators of other companies are the main basis for passing decisions on investment.

Variants of response are: 5 - agree, 4 - rather agree, 3 - nor agree neither disagree, 2 - rather disagree, 1 - disagree.

Estimates are as follows: average 2.40, in-between 'rather disagree', and 'nor agree neither disagree', mode 2 and median 2. Low estimates are related to failed investments made by Estonian companies.

\section{In the following, the results of the survey have been analyzed according to these categories:}

1) based on the size of the company - companies with more than 250 employees and companies with 50-249 employees; 2) based on the role of the respondent - accountant or finance manager; 3) based on the use of Format 1 or Format 2; 4) based on the field of operations of the company.

Tables 4 and 6 present mean values of responses to all questions surveyed, respectively to compare estimates of companies with number of employees $\geq 250,50-249$ and all respondent companies and to compare estimates of accountants, finance managers and all respondents together. Table 7 presents the data on how the use of profit figures differs between those using Format 1 and Format 2. Table 8 presents the estimates as per branches of activity. The hypotheses have been subject to check (z-test): 1. In large companies the analysis is stronger than that in smaller ones. 2. The finance manager (analyst) handles the analysis more thoroughly than the accountant does. 3. Format 2 users handle the analysis more thoroughly than Format 1 users. 
Table 4 reveals that the medium value of all indicators is higher in large companies. The arithmetic mean of estimates of use of different indicators of large companies is 3.18. With mid-size companies that indicator is 3.06. Z-test's empirical value is 0.53 , which does not however, on the significance level 5\%, exceed the $z$-test's critical value 1.645 in case of unilateral hypothesis. Thus, there are no grounds to reject the null hypothesis: the extent of use of finance indicators does not differ significantly with large and medium-size companies.

Table 4. Average values of all indicators, using estimates of different size companies

\begin{tabular}{|l|c|c|c|}
\hline \multicolumn{1}{|c|}{ Indicator } & All companies & $\begin{array}{c}\text { Companies with number of } \\
\text { employees } \geq 250\end{array}$ & $\begin{array}{c}\text { Companies with 50-249 } \\
\text { employees }\end{array}$ \\
\hline $\begin{array}{l}\text { Calculation of profitability } \\
\text { indicators }\end{array}$ & 4.06 & 4.24 & 4.01 \\
\hline Comparison with competitors & 3.08 & 3.37 & 2.95 \\
\hline Use of operating profit & 4.22 & 4.20 & 4.22 \\
\hline Use of gross profit & 4.01 & 4.00 & 4.03 \\
\hline Use of EBT & 3.43 & 3.13 & 3.53 \\
\hline Use of net profit & 4.14 & 4.17 & 3.11 \\
\hline Use of EBITDA & 3.67 & 3.98 & 2.50 \\
\hline Use of contribution margin & 2.63 & 2.75 & 1.93 \\
\hline Use of cash based profit & 1.94 & 3.15 & 2.91 \\
\hline $\begin{array}{l}\text { Adjustment of income } \\
\text { statement }\end{array}$ & 2.97 & 1.93 & 2.15 \\
\hline Use of RI & 2.11 & 3.37 & 3.33 \\
\hline Use of EVA & 2.35 & 3.22 & 2.35 \\
\hline Use of ROI & 2.39 & 2.49 & 2.20 \\
\hline $\begin{array}{l}\text { Profit indicators of other } \\
\text { companies as the basis for } \\
\text { making investment decisions }\end{array}$ & & & \\
\hline $\begin{array}{l}\text { Distinction between return on } \\
\text { capital } \text { and return of capital } \\
\text { improves management } \\
\text { decisions }\end{array}$ & 2.43 & 3.18 & 3.06 \\
\hline $\begin{array}{l}\text { Arithmetic mean across all } \\
\text { indicators }\end{array}$ & 3.10 & & \\
\hline
\end{tabular}

The following presents for comparison the results of the survey carried out in Slovenia in 2008 (Marc et al. 2010). Ninety-three large companies were asked about their opinion of 10 important indicators for performance evaluation. The questionnaire was constructed using a 5grade Likert-scale. In table 5 indicators that are by content comparable with the indicators observed in the present survey are in bold.

Table 5. The most important performance measures in Slovenian large companies in 2008 (1 - unimportant; 2 - of little importance; 3 - medium; 4 - important; 5 - very important)

\begin{tabular}{|l|c|}
\hline Performance measure & Mean \\
\hline Revenues growth & 4.22 \\
\hline Profit growth & 4.18 \\
\hline Liquidity & 4.15 \\
\hline Revenues to cost ratio & $\mathbf{4 . 1 2}$ \\
\hline Solvency & 4.00 \\
\hline Days sales outstanding & 4.00 \\
\hline ROE & $\mathbf{3 . 9 5}$ \\
\hline Contribution margin & $\mathbf{3 . 9 3}$ \\
\hline Value added & $\mathbf{3 . 8 7}$ \\
\hline Days payable outstanding & 3.86 \\
\hline
\end{tabular}

Source: (Marc et al. 2010) 
Revenues to cost ratio -4.12 and $R O E-3.95$ are by content closely comparable with the Estonian survey's indicator "Calculation of profitability indicators" for large companies in Estonia - 4.24. Contribution margin - 3.93 is comparable with the Estonian survey's "Use of contribution margin" -2.75 , Value added -3.87 in the Slovenian survey can by content be paralleled with EVA and $R I$ in the Estonian survey - the values of these indicators are 2.37 and 1.93 .

To continue with the analysis of the survey carried out in Estonia: it needs be pointed out that the use of almost every indicator is higher when analysis is carried out by finance managers (Table 6). This supports the assumption that the Estonian companies have historically developed an opinion (and practice), under which the accountant is generally not required to carry out such analysis. The companies, which have instituted a separate office of the finance analyst to perform this task, display a higher level of analysis.

Table 6. Average values of all indicators, using estimates of accountants and financial analysts

\begin{tabular}{|l|c|c|c|}
\hline \multicolumn{1}{|c|}{ Indicator } & $\begin{array}{c}\text { All } \\
\text { respondents }\end{array}$ & $\begin{array}{c}\text { Estimates of } \\
\text { finance managers }\end{array}$ & $\begin{array}{c}\text { Estimates of } \\
\text { accountants }\end{array}$ \\
\hline Calculation of profitability indicators & 4.06 & 4.50 & 3.37 \\
\hline $\begin{array}{l}\text { Use of income statement for comparison with } \\
\text { competitors }\end{array}$ & 3.08 & 3.24 & 2.74 \\
\hline Use of operating profit & 4.22 & 4.39 & 3.98 \\
\hline Use of gross profit & 4.01 & 4.10 & 3.79 \\
\hline Use of EBT & 3.43 & 3.46 & 3.35 \\
\hline Use of net profit & 4.14 & 4.05 & 4.26 \\
\hline Use of EBITDA & 3.67 & 3.95 & 3.21 \\
\hline Use of contribution margin & 2.63 & 2.60 & 2.55 \\
\hline Use of cash based profit & 1.94 & 1.92 & 1.98 \\
\hline Adjustment of income statement & 2.97 & 3.19 & 2.63 \\
\hline Use of RI & 2.11 & 2.10 & 2.15 \\
\hline Use of $E V A$ & 2.35 & 2.30 & 2.24 \\
\hline Use of ROI & 3.12 & 3.47 & 2.61 \\
\hline $\begin{array}{l}\text { Profit indicators of other companies as the basis for } \\
\text { making investment decisions }\end{array}$ & 2.39 & 2.30 & 2.56 \\
\hline $\begin{array}{l}\text { Distinction between } \text { return on capital and return of } \\
\text { capital } \text { improves management decisions }\end{array}$ & 2.43 & 2.53 & 2.11 \\
\hline Arithmetic mean across all indicators & 3.10 & 3.21 & 2.90 \\
\hline
\end{tabular}

The arithmetic mean of range of use of all indicators by finance managers is 3.21 , by accountants 2.90. The z-test's empiric value is 1.31 , which, however, does not on the significance level 5\%, exceed the $z$-test's critical value 1.645 in case of unilateral hypothesis. Thus there are no grounds to reject the null hypothesis: the extent of use of finance indicators does not differ significantly with finance managers and accountants.

Although the z-test does not suggest the statistical difference, the use of almost every indicator is higher when analysis is carried out by finance managers. This finding suggests the need to change attitudes about the role of accountants - the accountant should be engaged in the analysis. On the one hand, this would improve the level of analysis in the companies, which lack a separate office. On the other hand, involvement of an accountant in the process of analysis would enlarge his/her view on finance data and financial statements, which would spur in the Estonian society a accounting-related discussion and would enhance the conceptual level of the practice of financial accounting.

According to the Estonian Accounting Act, every company can choose whether to prepare its annual accounts in accordance with International Financial Reporting Standards (IFRSs) or in 
accordance with the Estonian accounting guidelines (Estonian GAP). The companies, which have decided to follow Estonian guidelines must use one of the two income statement layouts: Format 1 (where items are classified by nature) or Format 2 (where items are classified by functions).

Regarding the usage of income statement Format 1 respondents identified 38\% and for the Format $256 \%$ level. There are also some companies, which use both formats $(6 \%$ of respondents). In the latter case, one of the formats is used for reporting and the other one for intra-company analysis.

Table 7 presents data on how the use of profit figures differ between those using Format 1 and Format 2. The use of all figures of income statement is higher with those using Format 2. Thus, we conclude that the companies, which attach value to analysis, have selected Format 2, which is generally considered more informative for the analysis. When regarding the off-income statement figures, i.e. contribution margin and cash-based profit, Format 1 users display somewhat higher indicators.

Table 7. Average values of all indicators, using estimates of users of Format 1 and Format 2

\begin{tabular}{|l|c|c|}
\hline \multicolumn{1}{|c|}{ Indicator } & Format 1 users & Format 2 users \\
\hline Calculation of profitability indicators & 3.86 & 4.38 \\
\hline Use of income statement for comparison with competitors & 3.03 & 3.14 \\
\hline Use of operating profit & 4.00 & 4.60 \\
\hline Use of gross profit & 3.90 & 4.24 \\
\hline Use of EBT & 3.24 & 3.68 \\
\hline Use of net profit & 4.08 & 4.38 \\
\hline Use of EBITDA & 3.45 & 3.96 \\
\hline Use of contribution margin & 2.82 & 2.48 \\
\hline Use of cash based profit & 2.01 & 1.86 \\
\hline Adjustment of income statement & 3.00 & 2.92 \\
\hline Use of RI & 2.11 & 2.12 \\
\hline Use of EVA & 2.32 & 2.34 \\
\hline Use of ROI & 2.96 & 3.41 \\
\hline $\begin{array}{l}\text { Profit indicators of other companies as the basis for making } \\
\text { investment decisions }\end{array}$ & 2.41 & 2.35 \\
\hline $\begin{array}{l}\text { Distinction between return on capital and return of capital } \\
\text { improves decisions }\end{array}$ & 2.39 & 2.51 \\
\hline Arithmetic mean across all indicators & 3.04 & 3.22 \\
\hline
\end{tabular}

The z-test shows that differences in use of indicators are not statistically meaningful. The empirical value of z-test statistics carried out based on arithmetic means of estimates revealed in survey is 0.880 , which in the case of unilateral hypothesis on significance level $5 \%$ does not top the statistics critical value 1.645. Thus, there are no grounds to reject the zerohypothesis: use of profit indicators with users of Format 1 and Format 2 in financial analysis does not differ significantly.

Of interest, too, is comparison of the use of different profit indicators among companies surveyed according to the branch of activities. Estimates of companies revealed by survey in terms of the activities of companies are presented in Table 8.

It appears from the Table 8 that on average, different profit indicators are used in financial analysis more frequently in industry and service areas, and less frequently in trade and the building sectors. Given this, the inherently more complicated business activities of the former calls for a deeper going analysis. 
Table 8. Estimates as per branch of activities of companies

\begin{tabular}{|c|c|c|c|c|}
\hline Indicator & $\begin{array}{c}\text { Industry and } \\
\text { energy }\end{array}$ & $\begin{array}{c}\text { Building and real } \\
\text { estate }\end{array}$ & Service & Trade \\
\hline Calculation of profitability indicators & 4.32 & 3.88 & 3.92 & 4.00 \\
\hline $\begin{array}{l}\text { Use of income statement for } \\
\text { comparison with competitors }\end{array}$ & 3.05 & 2.75 & 2.69 & 3.26 \\
\hline Use of operating profit & 4.52 & 3.88 & 4.38 & 3.91 \\
\hline Use of gross profit & 4.25 & 3.82 & 4.46 & 3.76 \\
\hline Use of EBT (pre-income tax profit) & 3.79 & 3.29 & 3.58 & 3.16 \\
\hline Use of net profit & 4.34 & 3.81 & 4.08 & 4.23 \\
\hline Use of EBITDA & 3.80 & 3.24 & 4.08 & 3.47 \\
\hline Use of contribution margin & 2.76 & 2.13 & 3.38 & 2.63 \\
\hline Use of cash based profit & 2.00 & 1.47 & 2.46 & 1.71 \\
\hline Adjustment of income statement & 2.84 & 3.12 & 3.85 & 2.80 \\
\hline Use of RI & 2.16 & 2.19 & 2.38 & 2.09 \\
\hline Use of EVA & 2.52 & 2.13 & 2.31 & 2.24 \\
\hline Use of ROI & 3.36 & 3.24 & 2.69 & 3.06 \\
\hline $\begin{array}{l}\text { Profit indicators of other companies as } \\
\text { the basis for making investment } \\
\text { decisions }\end{array}$ & 2.41 & 2.59 & 2.15 & 2.24 \\
\hline $\begin{array}{l}\text { Distinction between return on capital } \\
\text { and return of capital improves } \\
\text { management decisions }\end{array}$ & 2.44 & 1.83 & 2.27 & 2.69 \\
\hline Arithmetic mean across all indicators & 3.24 & 2.89 & 3.25 & 3.02 \\
\hline
\end{tabular}

The foregoing differences notwithstanding, the quality of analysis in the surveyed Estonian companies may be deemed as being relatively uniform: z-tests revealed a lack of statistical difference between all groups surveyed on significance level 0.05 .

\section{Conclusions}

As evidenced in the survey, some analysis of indicators of income and profitability is taking place in Estonian companies. Preference is given to less sophisticated indicators and methods. $67 \%$ of the respondent companies actually use the results of their profitability analysis in the management process. $14 \%$ of the respondents indicated that the results of profitability analysis do not meet with actual use.

It is necessary to point out that Estonian companies must pay more attention to indicators, allowing the monitoring of the actual growth of wealth in the company. The importance of profit as the indicator of change of the company value has presently gained prominence in the world, even more so given the current economic predicament. Prerequisites for that have been created by the comprehensive income conception recognized both by the IASB and by the FASB.

In addition, the cash-based profit calls for due attention in companies. Dismissing the cashbased profit analysis may suddenly result in the company's insolvency. The latter attitude can be accounted for by the misconception that is deeply rooted in the companies that accrual profit is of equal value to the amount-of-money collected.

With regard to the organization of analysis in the companies, it would be advisable to increase the role of an accountant as an analyst. This would allow the accountant to understand the accounting issues in various aspects.

The Estonian academician professor Uno Mereste developed the methodology of systemintegrated analysis in the 1980s (Mereste 1984; Mereste 1989; Mereste 1991). The authors suggest application of the method of system-integrated analysis as a viable option for 
enhancing the efficacy of the analysis of income statement and profitability. This method will enable the companies to focus on the interconnections of indicators and develop a composite index to measure overall profitability.

\section{Literature}

Barker, R. (2010). On the Definitions of Income, Expenses and Profit in IFRS. Accounting in Europe, 7 (2), pp. 147-158.

Bray, F. S. (1949). The Measurement of Profit. London: Oxford University Press.

Chambers, R. J. (1966). Accounting, Evaluation and Economic Behavior. New York: Prentice Hall.

Christensen, J., Demski, J. (2003). Accounting Theory. An Information Content Perspective. New York: McGraw-Hill.

Edwards, E. O., Bell, P. W. (1961). The theory and measurement of business income. Los Angeles: University of California Press.

Feltham, G. H., Ohlson, J. A. (1995). Valuation and Clean Surplus Accounting for Operating and Financial Activities. Contemporary Accounting Research, 11 (2), pp. 689-731.

Kasalis, J. (2005). Models of Company Financial Statement Analysis and Their Application to Different User Groups. Riga: University of Latvia.

Marc, M., Peljhan, D., Ponikvar, N., Sobota, A., Tekavcic, M. (2010). Performance Measurement in Large Slovenian Companies. An Assessment of Progress, 14 (1), pp. 129139.

Mereste, U. (1984). Kompleksanalüüs ja efektiivsus. Tallinn: Valgus.

Mereste, U. (1987). Majandusanalü̈̈si teooria. Tallinn: Valgus.

Mereste, U. (1991). Ettevõtete ja koondiste majandusliku tegevuse kompleksanalüüs. Tallinn: Eesti Majandusjuhtide Instituut.

Mosso, D. (2010). Transparency Unveiled: Financial Crisis Prevention Through Accounting Reform. Accounting Horizons, 24 (1), pp. 95-107.

Nobes, C. (2012). On the Definitions of Income and Revenue in IFRS. Accounting in Europe, 9 (1), pp. 85-94.

Ohlson, J. A. (1995). Earnings, Book Values, and Dividends in Equity Valuation. Contemporary Accounting Research, no. 11 (2), 662-687.

Ohlson, J. A. (1991). The theory of value and earnings and an introduction to the Ball-Brown analysis. Contemporary Accounting Research, no. 8, 1-19.

Ohlson, J. A. (1990). A Synthesis of Security Valuation Theory and the Role of Dividends, Cash Flows and Earnings. Contemporary Accounting Research, Spring, pp. 648-676.

Ohlson, J. A. (1989). Accounting Earnings, Book Value and Dividends: The Theory of the Clean Surplus Equation (Part I). Columbia University.

Riahi-Belkaoui, A. (2004). Accounting Theory. 5th Edition. London: Thomson Learning.

Schroeder, R., Clark, M., Cathey, J. (2012). Financial Accounting: Theory and Analysis. New York: John Wiley \& Sons.

Scott, W. R. (2015). Financial Accounting Theory. 7th Edition. Toronto: Pearson. 
Spaller, R. (2006). Leveraging Contribution Margin to Gain a Competitive Advantage. Journal of Performance Management, 19 (2), pp. 45-57.

Sterling, R. R. (1971). On Theory Construction and Verification. The Accounting Review, January, 12-29.

Stern, J. M., Stewart, G. B., Chew, D. H. (1996). EVA: An Integrated Financial Management System. European Financial Management, 2 (2), pp. 223-245.

Subatnieks, K. (2007). Application of Cash Flow in Corporate Financial Analysis. University of Latvia. 


\section{Questionnaire for assessment of profitability measurement activities in Estonian companies}

1. I use the income statement when analyzing the performance of the company:

a) For calculating the efficiency indicators
$\square$ Never at all
$\square$ Very rarely
$\square$ Sometimes
$\square$ Frequently $\square$ Always

b) As the background enabling comparison with competitors
$\square$ Never at all
$\square$ Very rarely
$\square$ Sometimes
$\square$ Frequently $\square$ Always

c) For other purposes. Please specify
$\square$ Never at all
$\square$ Very rarely
$\square$ Sometimes
$\square$ Frequently
$\square$ Always

2. When analyzing, I use the following income numbers (please provide an estimate to all of them):

a) Operating profit

$\square$ Never at all $\square$ Very rarely $\square$ Sometimes $\square$ Frequently $\square$ Always

b) Gross profit

$\square$ Never at all $\square$ Very rarely $\square$ Sometimes $\square$ Frequently $\square$ Always

c) Earnings before taxes (EBT)

$\square$ Never at all $\square$ Very rarely $\square$ Sometimes $\square$ Frequently $\square$ Always

d) Net profit

$\square$ Never at all

$$
\square \text { Very rarely } \square \text { Sometimes } \square \text { Frequently } \square \text { Always }
$$

e) Earnings before interest and taxes and depreciation (EBITDA)
$\square$ Never at all
$\square$ Very rarely
$\square$ Sometimes
$\square$ Frequently $\square$ Always

f) Marginal profit (Contribution margin, residual income)
$\square$ Never at all
$\square$ Very rarely
$\square$ Sometimes
$\square$ Frequently $\square$ Always

g) Cash based income

$\square$ Never at all $\square$ Very rarely $\square$ Sometimes $\square$ Frequently $\square$ Always

h) Other. Please specify
$\square$ Never at all
$\square$ Very rarely
$\square$ Sometimes
$\square$ Frequently
$\square$ Always

3. For the analysis needed by the company, I adjust the regular income statement (and balance sheet).
$\square$ Never at all
$\square$ Very rarely
$\square$ Sometimes
$\square$ Frequently $\square$ Always

4. I calculate the following financial indicators:

a) RI (Residual income)
$\square$ Never at all
$\square$ Very rarely
$\square$ Sometimes
$\square$ Frequently $\square$ Always
b) EVA (Economic value added)
$\square$ Never at all $\square$ Very rarely
$\square$ Sometimes $\square$ Frequently $\square$ Always
c) ROI (Return on investment)
$\square$ Never at all $\square$ Very rarely $\square$ Sometimes $\square$ Frequently $\square$ Always

5. The income indicators of other companies are the main basis for taking investment decisions.
$\square$ I disagree
$\square$ I rather disagree
$\square$ I neither agree nor disagree
$\square$ I rather agree
$\square$ I agree

6. Making difference between return on capital and return of capital essentially improves the management decisions.

$\square$ I disagree $\quad \square$ I rather disagree $\quad \square$ I neither agree nor disagree $\quad \square$ I rather agree $\quad \square$ I agree

7. Are the results of your analysis used in practice?
$\square$ Yes
$\square$ No
$\square$ I cannot say

8. Is your salary dependent on the amount of profit?
$\square$ No
$\square$ Rather no
$\square$ Rather yes
$\square$ Yes

9. Do you use

$\square$ Scheme 1

$\square$ Scheme 2 
10. Your position

$\square$ Accountant $\square$ Financial Manager

11. Number of employees of your company

$\square 250$ plus $\quad \square 50-249$

12. Area of business of your company

$\square$ Industry and energy $\quad \square$ Building and real estate development $\quad \square$ Trade $\quad \square$ Service 